\title{
Seedling imaging analysis and traditional tests to assess okra seed vigor ${ }^{1}$
}

\author{
Ana Lúcia Pereira Kikuti2*, Júlio Marcos-Filho³
}

\begin{abstract}
Seed vigor testing is an important component of quality control programs adopted by seed industry. The software Seed Vigor Imaging System (SVIS) has been successfully used for seed vigor assessment in different species. The objective of this research was to verify the SVIS efficiency to assess okra seed vigor in comparison to other vigor tests used for this species. Five seed lots of 'Clemson Americano' and four of 'Santa Cruz' were submitted to germination (speed and percentage), cold germination (speed and percentage), traditional and saturated salt accelerated aging $\left(41{ }^{\circ} \mathrm{C} / 72\right.$ and $\left.96 \mathrm{~h}\right)$ and seedling emergence tests during 12 months storage. Vigor index, uniformity of growth and seedling length were determined by the software Seed Vigor Imaging System (SVIS). Results showed that the vigor index and seedling length determined by the SVIS analyses are efficient to determine okra seed vigor as well as the accelerated aging test $\left(41^{\circ} \mathrm{C} / 72 \mathrm{~h}\right)$.
\end{abstract}

Index terms: Abelmoschus esculentus L., seed analysis, physiological potential.

\section{Análise de imagens de plântulas e testes tradicionais para avaliação do vigor de sementes de quiabo}

RESUMO - A avaliação do vigor é essencial em programas de controle de qualidade das empresas produtoras de sementes. Uma das alternativas mais recentes para essa avaliação é o sistema computadorizado de análise de imagens de plântulas (SVIS), utilizado com sucesso para várias espécies de sementes de grandes culturas e de hortaliças. O objetivo desta pesquisa foi verificar a eficiência do SVIS para identificar diferenças no potencial fisiológico de lotes de sementes de quiabo, em comparação com outros métodos utilizados para essa espécie. Cinco lotes da cultivar Clemson Americano e quatro da 'Santa Cruz' foram submetidos a testes de germinação (velocidade e porcentagem), germinação a baixa temperatura $\left(15^{\circ} \mathrm{C}\right)$, envelhecimento acelerado tradicional e com solução saturada de $\mathrm{NaCl}$ ( $41^{\circ} \mathrm{C} / 72$ e 96 horas) e emergência de plântulas. Também foi determinado o índice de vigor, o comprimento e a uniformidade de desenvolvimento de plântulas, por meio do SVIS. Essas avaliações foram realizadas no início, aos seis e doze meses de armazenamento. Concluiu-se que o índice de vigor e o comprimento de plântulas, avaliados por meio do software SVIS, são eficientes para identificar diferenças de vigor de lotes de sementes de quiabo, proporcionando resultados semelhantes aos obtidos no teste de envelhecimento acelerado $\left(41^{\circ} \mathrm{C} / 72\right.$ horas $)$.

Termos de indexação: Abelmoschus esculentus L., análise de sementes, potencial fisiológico.

\section{Introduction}

Vigor tests have emerged to complement the information obtained from the germination test, which may overestimate the physiological potential of seed lots. Vigor tests can provide information closer to what occurs during seedling establishment in the field, because they are based on physiological and biochemical characteristics sensitive to changes in seed physiological potential before those identified in the germination test. Although researches to estimate the level of okra seed vigor are scarce, it has been recommended to use the accelerated aging

${ }^{1}$ Submitted on $1 / 25 / 2013$. Accepted for publication on $8 / 13 / 2013$.

${ }^{2}$ Instituto Federal de Ciência e Tecnologia do Triângulo Mineiro - IFMT. 38400-970 - Uberlândia, MG, Brasil.

${ }^{3}$ Departamento de Produção Vegetal, USP/ESALQ, Caixa Postal 9, test, at $41^{\circ} \mathrm{C} / 72 \mathrm{~h}$ for this species (Dias et al., 1998 and Lopes et al., 2010) and $41{ }^{\circ} \mathrm{C} / 144 \mathrm{~h}$ (Torres and Carvalho, 1998). On the other hand, using the saturated salt test procedure, Lopes et al. (2010) indicated the combination $41^{\circ} \mathrm{C} / 72 \mathrm{~h}$, as appropriate to detect vigor differences among the samples evaluated. Also, in the seed vigor electrical conductivity test, the combination of 50 seeds $/ 75 \mathrm{~mL}$ of water $/ 24 \mathrm{~h} / 25^{\circ} \mathrm{C}$ was considered efficient by Dias et al. (1998).

Modern procedures have been studied to assess the physiological potential of the seeds, among them the computerized seedling imaging analysis. In this technique, the determination of

13418-900 - Piracicaba, SP, Brasil. Scholarship holder of CNPq (Conselho Nacional de Desenvolvimento Científico e Tecnológico - National Counsel of Technological and Scientific Development)

*Corresponding author<alpkikuti@gmail.com> 
the vigor is performed more quickly and without the direct human interference. It was used initially by McCormac et al. (1990), developing an automatic system for the determination of the average length of the primary roots of tomato seedlings.

Further work was carried out later, especially by Ducournau et al. (2005), using an imaging analysis technique to determine the time required for the germination of sunflower seeds and by Tohidloo and Kruse (2009), to evaluate the growth of radish seedlings by of an image analysis system and associating these data to those obtained on field seedling emergence. A software that has been used for determining seedling vigor is "Seed Vigor Imaging System $^{\circledR}$ " (SVIS), developed at Ohio State University/USA. This software performs the digital processing of images of scanned seedlings and establishes vigor and uniformity indexes, besides providing average values of seedling length.

This software was initially used by Sako et al. (2001) to assess lettuce seed vigor by capturing images of three-day old seedlings and determination of vigor and uniformity indexes, hypocotyl and primary root lenght, and root/hypocotyl ratio. This software has been successfully adapted to evaluate, among others, soybean seeds by (Hoffmaster et al., 2003) corn (Hoffmaster et al., 2005), melon (Marcos-Filho et al., 2006), supersweet corn (Alvarenga et al., 2012), sunhemp (Silva et al., 2012) and cucumber (Chiquito et al., 2012) seed vigor.

To confirm the efficiency of the software, studies are needed to compare the information provided by SVIS analyses with results from tests already recommended, adapting the methodology for the different species. In this sense, Kikuti and Marcos-Filho (2012) identified the SVIS software as a promising tool for the analysis of lettuce seed vigor in comparison to traditional methods, an observation that was not performed by Sako et al. (2001).

This study aimed to verify the efficiency of the seedling imaging analysis by the SVIS software to assess okra seed vigor.

\section{Materials and Methods}

Research was conducted at the Laboratory of Imaging Analysis and at Seed Analysis Laboratory of the "Escola Superior de Agricultura Luiz de Queiroz (LPV/ESALQ)", University of São Paulo (USP) in Piracicaba - SP.

Nine lots of okra seeds were used, being five of the Clemson Americano cultivar and four of the Santa Cruz cultivar. These lots were homogenized and divided into five sub-samples each; the first subsample from each lot was used for the initial assessment of seed physiological potential and the other, packed in aluminized plastic bags hermetically sealed and stored for 12 months under laboratory environmental conditions. The assessments of the physiological potential were performed at the beginning of storage and in four-month intervals by the following tests. Germination - four replicates of 50 seeds were used and germinated according to the conditions described in the Rules for Seed Testing (Brasil, 2009). Daily counts from the fourth day were carried out until the tenth day after sowing, counting the normal seedlings for calculating the speed of germination index, according to Maguire (1962). The mean percentage of germination for each lot and cultivar was obtained based on the number of normal seedlings totaled at 10 days after sowing. Germination at low temperature conducted by the same procedure adopted for the germination test at $15^{\circ} \mathrm{C}$, in which normal seedling counts were performed between the twelfth and eighteenth days after installation of the test to obtain the index of germination speed. The average percentage of germination under low temperature was obtained based on the number of normal seedlings recorded at 28 days after sowing. Accelerated aging - the seeds from each lot were distributed on screens in a single layer inside plastic boxes $(11 \mathrm{~cm} \times 11 \mathrm{~cm} \times 3 \mathrm{~cm})$, containing $40 \mathrm{~mL}$ of water, to obtain $100 \%$ of relative air humidity. The boxes with seed samples were kept in a germination chamber at $41^{\circ} \mathrm{C}$, during 72 and $96 \mathrm{~h}$. After each aging period, seeds were submitted to germination test and the percentages of normal seedlings were calculated at four days after sowing. Saturated salt accelerated aging (SSAA) - conducted in the same manner described for the traditional test; but the water was replaced by $40 \mathrm{~mL}$ of saturated solution of sodium chloride, aiming to provide an environment with $76 \%$ of relative air humidity. Seedling emergence - four replicates of 50 seeds were distributed in individual cells of Styrofoam trays containing commercial substrate, kept in a greenhouse, irrigated daily. The assessment of the final percentage of seedling emergence was performed 21 days after sowing. Seed water content performed before all tests and after the the accelerated aging periods, by the oven method, at $105^{\circ} \mathrm{C}$ for $24 \mathrm{~h}$, according to the Rules for Seed Testing (Brasil, 2009).

Seedling vigor imaging system (SVIS) -germination was performed in paper-towel rolls, with four replications of 25 seeds for each lot distributed in the upper third of the paper towel surface and germinated at $25^{\circ} \mathrm{C}$ for four days, for both cultivars. Normal seedlings from each replicate were transferred from the germination paper to a sheet of black cardboard to provide contrast between the seedlings and the black background during the capture of images by a scanner machine. The images were captured on an inverted scanner model HP Scanjet 2004 mounted within an aluminum apparatus and operated by a Photosmart software with a resolution of 100 dpi. Scanned images were analyzed by the SVIS software, installed on a 
Pentium IV computer, operated by the Windows XP Profissional system. After the digital processing of the images and individual analysis of each seedling root / hypocotyls axis were generated by means of the SVIS software, the numerical values of the vigor index and of uniformity of seedling development, which may vary from 0 to 1000 . The assessment of the seedling length was performed by positioning the cursor over each seedling, automatically obtaining its length, in millimeters; results were expressed as mean values for each lot and cultivar.

Statistical analysis of the data obtained in the different tests was performed comparing the lots within each cultivar for each assessment and testing times. The SISVAR program was used and the Tukey test $(p \leq 0.05)$ for comparing the averages.

\section{Results and Discussion}

Analysis of variance of the data obtained from traditional tests detected significant differences among seed lots in both cultivars, in most tests performed, except for seedling emergence, for cultivar Clemson Americano, at 12-month storage; saturated salt accelerated aging $\left(41^{\circ} \mathrm{C} / 96 \mathrm{~h}\right)$, before storage; speed of germination and saturated salt accelerated aging $\left(41^{\circ} \mathrm{C} / 72 \mathrm{~h}\right.$ and $96 \mathrm{~h}$ ), after six months of storage and speed of germination at 12 months of storage, for 'Santa Cruz'.

Significant differences were observed among lots for vigor index and seedling length by SVIS software, for both cultivars studied in all evaluation times. For uniformity of seedling development, there was a difference among lots at 6 months of storage, for cultivar Clemson Americano, and at the initial time and at 6 months of storage, for Santa Cruz cultivar.

The germination percentage of both cultivars exceeded the minimum established for marketing of okra seeds which is of (75\%), according to Brasil (2010). To determine the efficiency of vigor tests it is important to evaluate lots over the requirements established for the marketing of seeds, because these tests provide additional information to the germination test and this information is not needed to characterize the lots that will not be marketed as seeds.

Seed water content of different lotsbefore the tests ranged from $10 \%$ to $12 \%$ in all evaluation times, in both cultivars (data not shown). After the aging period for the SSAA, seed water content among lots was between $11 \%$ and $13 \%$. This result is expected since the low relative humidity provided by the saturated salt solution restricts the seed water uptake during the test. Similarly to that observed in this study, a slight increase in the water content of okra seeds after the accelerated aging period was verified by Lopes et al. (2010).

The accelerated aging test has as principle the increased rate of seed deterioration when exposed to high temperature and relative humidity. When using the saturated salt solution, the humidity effect is attenuated, prevailing that from aging temperature. Therefore, this procedure causes less drastic effects than the traditional accelerated aging.

After the traditional accelerated aging, seed water content ranged from $25 \%$ to $34 \%$, considering the two exposure periods ( 72 and $96 \mathrm{~h}$ ) and the three evaluation times, not exceeding the range of four percentage points among seed lots within the same temperature and time adopted here for this test. These variations in water content probably did not affect the test results, as they were within tolerable limits, according to Marcos-Filho (1999).

With respect to the cultivar Clemson Americano seeds, the germination and seedling emergence tests identified lot 5 as the worst performance in the evaluations performed at zero and six months of storage (Table 1). In addition, at 12 months of storage, the germination test also identified lots 1 and 5 as the the worst performance, similarly to other traditional tests before storage. The seedling emergence test was conducted under environmental conditions closer to ideal and therefore its result was similar to that obtained in the germination test.

The SVIS software, considering the parameters vigor index and seedling length identified lot 1 as the lowest vigor at the first evaluation time, thus providing the same information from the germination test regarding the lots of worse performance. These parameters, at 6 and 12 months of storage, also highlighted lots 1 and 5 as the worst performance, and lots 2 and 3 as the best, in a similar way to the other tests performed here. These results indicate the possibility for the SVIS software to be used efficiently to determine okra seed vigor, as was already been observed for other species such as lettuce (Sako et al., 2001 and Kikuti and Marcos-Filho, 2012), corn (Otoni and McDonald, 2005), soybeans (MarcosFilho et al., 2009) and cucumber (Chiquito et al., 2012).

The evaluation of uniformity of seedling development detected differences between lots after six months of storage, highlighting the superiority of lots 2 and 3 in comparison to lot 5. This parameter was not considered as effective to identify differences in the physiological potential among soybean seed lots of high vigor (Marcos-Filho et al., 2009) and this is expected because high vigor is usually associated to uniform seed performance with respect to germination.

On the other hand, considering all five evaluation times for 'Santa Cruz'seeds, lot 6 was identified as the highest in vigor and superior to lot 9 in most tests (Table 2). Exceptions were observed in the SSAA for $96 \mathrm{~h}$ at zero and six months of storage and after $72 \mathrm{~h}$ aging period at six months of storage; speed of germination at six and 12 months of storage and uniformity of seedling development (SVIS) at 12 months of storage. 
Table 1. Speed (SG) and percentage $(\mathrm{G})$ of germination, speed $\left(\mathrm{SG}^{* *}\right)$ and percentage $\left(\mathrm{G}^{*}\right)$ of germination at low temperature, percentage seedling emergence (E), traditional (TAA) and saturated salt (SSAA) accelerated aging, vigor index (VI), uniformity of seedling development (U) and seedling length (SL) from the SVIS software, from different seed lots of okra cultivar Clemson Americano, during storage.

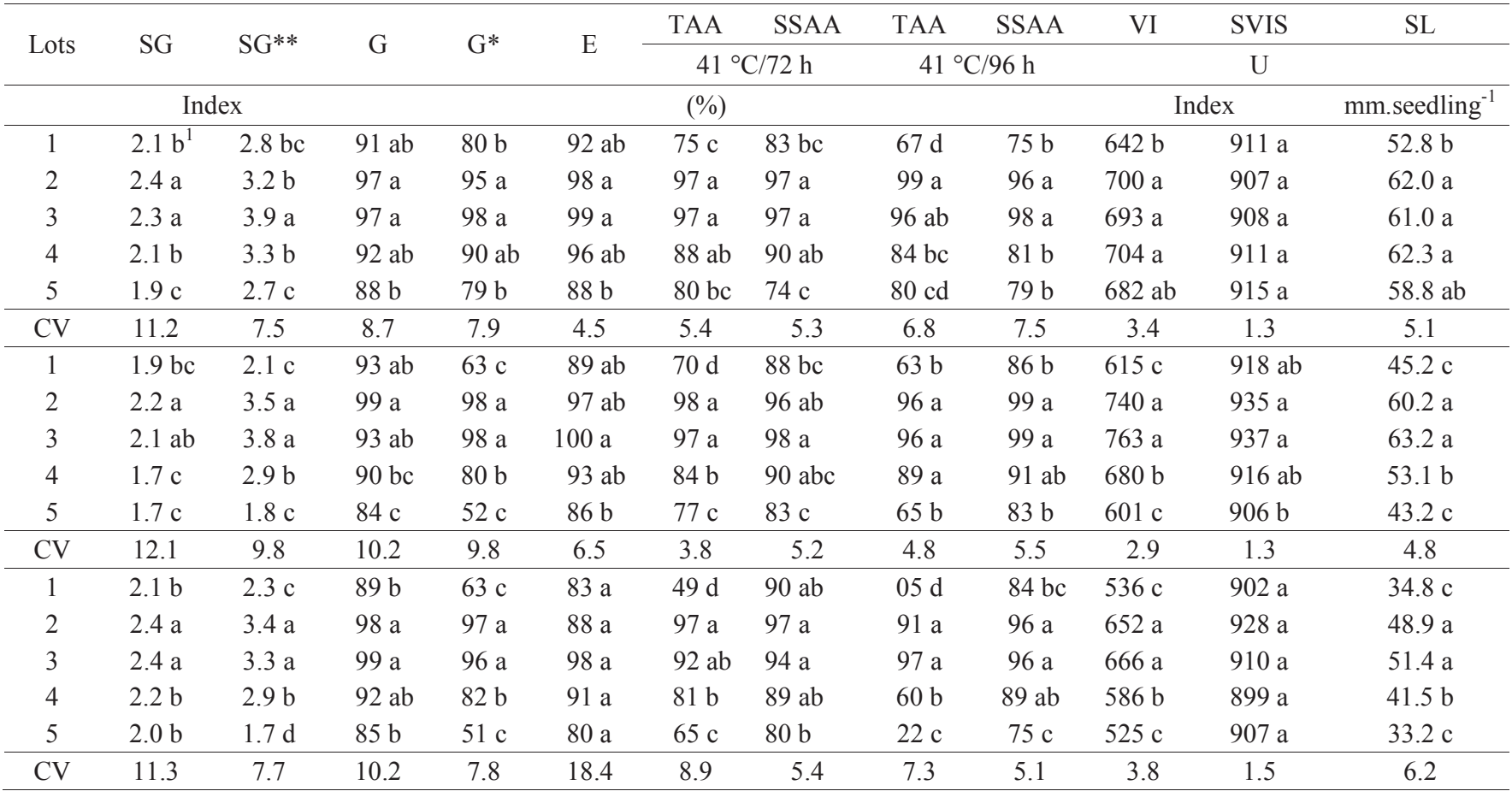

${ }^{1}$ Means comparison within each column (Tukey test, $\mathrm{P}<0.05$ ).

Table 2. Speed (SG) and percentage $(\mathrm{G})$ of germination, speed $\left(\mathrm{SG}^{* *}\right)$ and percentage $\left(\mathrm{G}^{*}\right)$ of germination at low temperature, percentage seedling emergence (E), traditional (TAA) and saturated salt (SSAA) accelerated aging, vigor index (VI), uniformity of seedling development (U) and seedling length (SL) fromthe SVIS software, from different seed lots of okra cultivar Santa Cruz, during storage.

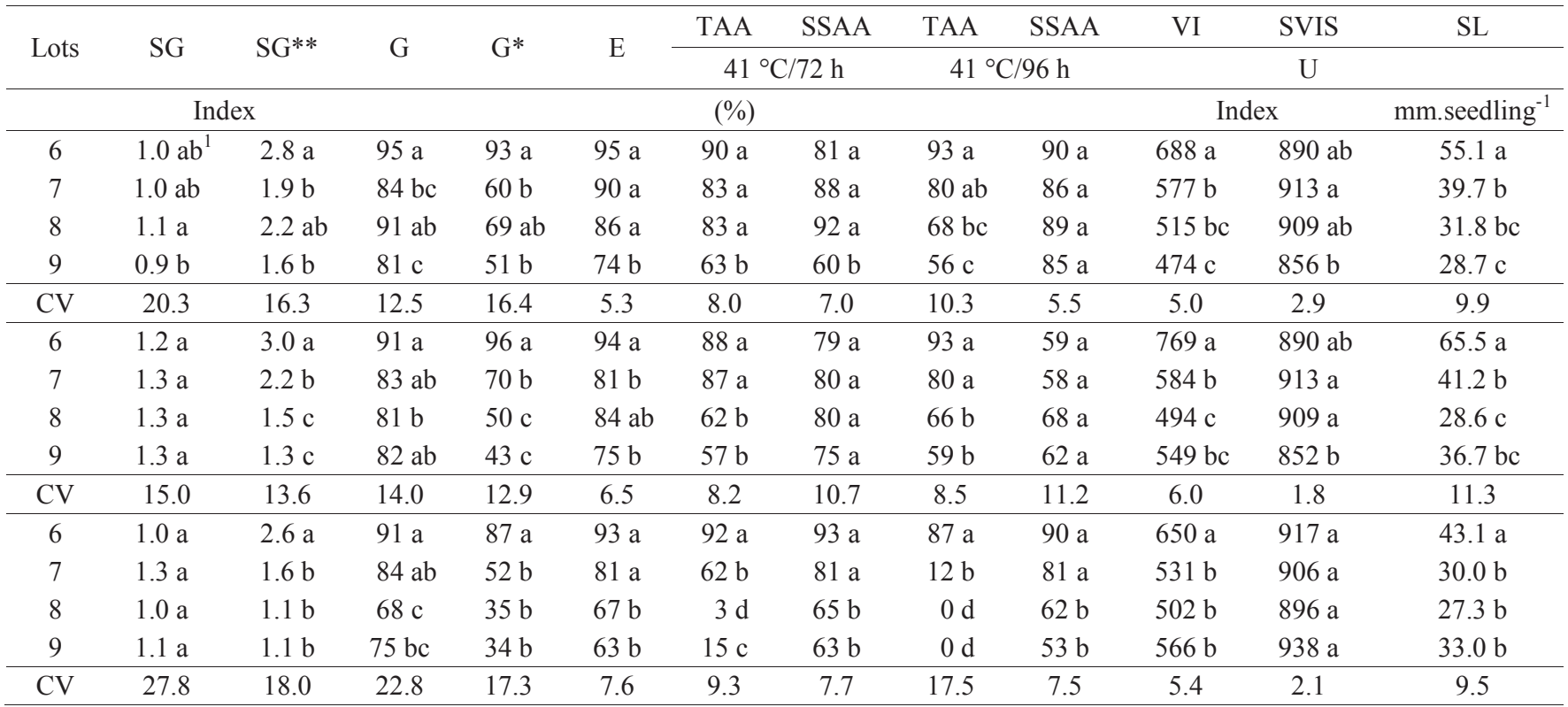

${ }^{1}$ Means comparison within each column (Tukey test, $\mathrm{P} \leq 0.05$ ) 
Seed lot 8 was identified, together with lot 9 , as the lowest vigor, by the results of the traditional accelerated aging test $\left(41^{\circ} \mathrm{C} / 96 \mathrm{~h}\right)$, vigor index and seedling length obtained with the SVIS program before the storage period. Similar results were observed in the germination tests at low temperature, traditional accelerated aging and vigor index and seedling length by SVIS. In germination, seedling emergence and saturated salt accelerated aging tests, this result was only observed at 12 months of storage.

In this research it was found that the accelerated aging test at $41{ }^{\circ} \mathrm{C}$ during $72 \mathrm{~h}$ was more appropriate for the assessment of okra seed vigor than the period of $96 \mathrm{~h}$, considered as too drastic. Such combination was also indicated by Dias et al. (1998) and by Lopes et al. (2010) for evaluation of the okra seeds vigor.

The vigor index and seedling length values obtained by SVIS provided the separation of the lots at different vigor levels in both cultivars studied, similarly to the more efficient traditional testing procedures.

Tests based on seedling development are successfully used to determine seed physiological potential of various species (Nakagawa, 1999). The determination of the root length, either manually or by means of SVIS, allowed to distinguish vigor level of lettuce seed lots (Nascimento and Pereira, 2007; Kikuti and Marcos-Filho, 2012). Similarly, the variable seedling growth was the more sensitive SVIS parameter to assess soybean seed vigor, with results comparable to those of the accelerated aging test (Marcos-Filho et al., 2009).

During storage there was a decrease in the physiological potential of seed lots, especially those of lower initial vigor, in both cultivars (Tables 1 and 2). In general, the accelerated aging tests, speed and percentage of germination at low temperature and the vigor index and seedling length by SVIS were similar to rank the lots in different vigor levels, in all evaluation times.

The germination test at low temperature, although effective to separate lots according to vigor is slower when compared to the other tests used here. The evaluation of the speed of germination was performed only from the 12th to the 18th days after sowing and the germination percentage was recorded only at 28 days. In the traditional vigor tests, the results were mostly obtained within 10 days, and in four days by SVIS.

The delay to obtain the results of germination at low temperature compared to other tests performed here makes difficult to recommend this test to compose seed quality control programs by seed companies because fast and reliable results are necessary to provide information for prompt use and support correct decisions during various pre and post-harvest phases of seed production. However, in this research the temperature of $15{ }^{\circ} \mathrm{C}$ was used, which may have been drastic to okra seeds. For cotton seeds (same family as okra - Malvaceae), the germination test at $18^{\circ} \mathrm{C}$, with seedling interpretation at seven days after sowing, has been considered as efficient (Mattioni et al., 2009). According to Dias and Alvarenga (1999), the temperature recommended for this test is between $15^{\circ} \mathrm{C}$ and $18^{\circ} \mathrm{C}$, depending on the species.

\section{Conclusions}

The vigor index and the seedling length, assessed by the SVIS software, are efficient to classify okra seeds lots according to the vigor level, providing results similar to those obtained in the accelerated aging test $\left(41^{\circ} \mathrm{C} / 72 \mathrm{~h}\right)$.

\section{Acknowledgments}

To FAPESP and to CNPq for the granting of scholarships and resources to conduct the research.

\section{References}

ALVARENGA, R.O.; MARCOS-FILHO, J.; GOMES JÚNIOR, F. G. Avaliação do vigor de sementes de milho superdoce por meio da análise computadorizada de imagens de plântulas. Revista Brasileira de Sementes, v. 34, n. 3, p. 488-494, 2012. http://dx.doi.org/10.1590/S010131222012000300017

BRASIL. Ministério da Agricultura, Pecuária e Abastecimento. Regras para análise de sementes. Ministério da Agricultura, Pecuária e Abastecimento. Secretaria de Defesa Agropecuária. Brasília: MAPA/ACS, 2009. 395 p. http://www.bs.cca.ufsc.br/publicacoes/regras\%20analise $\% 20$ sementes.pdf

BRASIL. Ministério da Agricultura, Pecuária e Abastecimento. Padrões de identidade e qualidade para a produção e a comercialização de sementes de espécies olerícolas, condimentares, medicinais e aromáticas. Instrução normativa de 15 de abril de 2010. Diário Oficial, Brasília, sec. 1, n. 73, p. 15 de 19/04/2010, 2010. http://www.members.wto.org/crnattachments/2010/sps/ BRA/10 1974 00 x.pdf

CHIQUITO, A. A.; GOMES JÚNIOR, F. G.; MARCOS-FILHO, J. Assessment of physiological potential of cucumber seeds using the software seedling vigor imaging system (SVIS). Revista Brasileira de Sementes, v. 34, n. 2, p. 255-263, 2012. http://dx.doi.org/10.1590/S0101-31222012000200010

DIAS, D. C. F. S.; ALVARENGA, E. M. Teste de germinação a baixa temperatura. In: KRZYZANOWSKI, F. C.; VIEIRA, R. D.; FRANÇA-NETO, J. B. (Ed.). Vigor de sementes: conceitos e testes. Londrina: ABRATES, 1999. Cap. 7, p. 1-4.

DIAS, D. C. F. S.; VIEIRA, A. N.; BHÉRING, M. C. Condutividade elétrica e lixiviação de potássio para avaliação do vigor de sementes de hortaliças: feijão vagem e quiabo. Revista Brasileira de Sementes, v. 20, n. 2, p. 408-413, 1998.

DUCOURNAU, S.; FEUTRY, A.; PLAINCHAULT, P.; REVOLLON, P. V.; VIGOUROUX, B.; WAGNER, M. H. Using computer vision to monitor germination time course of sunflower (Helianthus annuиs L.) seeds. Seed Science and Technology, v. 33, p. 329-340, 2005. http://www.ingentaconnect. com/content/ista/sst/2005/00000033/00000002/art00006\#expand/collapse 
HOFFMASTER, A. L.; FUJIMURA, K.; McDONALD, M. B.; BENNETT, M. A. An automated system for vigor testing three-day-old soybean seedlings. Seed Science and Technology, v. 31, p. 701-713, 2003. http://www. ingentaconnect.com/content/ista/sst/2003/00000031/00000003/art 00019

HOFFMASTER, A. F.; XU, L.; FUJIMURA, K.; McDONALD, M. B.; BENNETT, M. A.; EVANS, A. F. The Ohio State University Seed Vigor Imaging System (SVIS) for soybean and corn seedlings. Seed Technology, v. 27, n. 1, p. 7-24, 2005. http://europepmc.org/ search/?page=1\&query=AUTH:\%22Hoffmaster + AF $\% 22$

KIKUTI, A. L. P; MARCOS-FILHO, J. Testes de vigor em sementes de alface. Horticultura Brasileira, v. 30, n. 1, p. 44-50, 2012. http://www. horticulturabrasileira.com.br/images/stories /30_1/20123017.pdf

LOPES, M. M.; SADER, R.; PAIVA, A. S.; FERNANDES, A. C. Teste de envelhecimento acelerado em sementes de quiabo. Bioscience Journal, v. 26, n. 4, p. 491-501, 2010. http://www.seer.ufu.br/index.php/biosciencejournal/ article/view/7126/5121

MAGUIRE, J. D. Speed of germination aid in selection and evaluation for seedling and vigor. Crop Science, v. 2, n. 2, p. 176-177, 1962.

MARCOS-FILHO, J.; BENNETT, M. A.; McDONALD, M. B.; EVANS, A. F.; GRASSBAUGH, E. M. Assessment of melon seed vigor by an automated computer imaging system compared to traditional procedures. Seed Science and Technology, v. 34, p. 485-497, 2006.

MARCOS-FILHO, J.; KIKUTI, A. L. P.; LIMA, L. B. Métodos para avaliação do vigor de sementes de soja, incluindo a análise computadorizada de imagens. Revista Brasileira de Sementes, v. 31, n. 1, p. 102-112, 2009. http://dx.doi.org/10.1590/S0101-31222009000100012

MARCOS-FILHO, J. Testes de envelhecimento acelerado. In: KRZYZANOWSKI, F. C.; VIEIRA, R. D.; FRANÇA-NETO, J. B. (Ed.). Vigor de sementes: conceitos e testes. Londrina: ABRATES, 1999. Cap. 3, p. 1-24.

MATtioni, F; AlBuQuerque, M. C. F.; MENDONÇA, E. A. F. Desempenho de sementes de algodoeiro submetidas a diferentes tipos de estresses. Revista Brasileira de Sementes, v. 31, n. 1, p. 80-85, 2009. http:// www.scielo.br/pdf/rbs/v31n1/a09v31n1.pdf
McCORMAC, A. C.; KEEFE, P. D.; DRAPER, S. R. Automated vigor testing of field vegetables using image analysis. Seed Science and Technology, v. 18, p. $103-112,1990$.

NAKAGAWA, J. Testes de vigor baseados no desempenho das plântulas. In: KRZYZANOWSKI, F. C.; VIEIRA, R. D.; FRANCCA-NETO, J. B. (Ed.) Vigor de sementes: conceitos e testes. Londrina: ABRATES, p. 2.1-2.24, 1999.

NASCIMENTO, W. M.; PEREIRA, R. S. Testes para avaliação do potencial fisiológico de sementes de alface e sua relação com a germinação sob temperaturas adversas. Revista Brasileira de Sementes, v. 29 p. 175-179, 2007. http://www.scielo.br/pdf/rbs/v29n3/a21v29n3.pdf

OTONI, R. R.; McDONALD, M. B. Moisture and temperature effects on maize and soybean seedlings using the seed vigor imaging system. Seed Technology, v. 27, n. 2, p. 243-247, 2005.

SAKO, Y.; McDONALD, M. B.; FUJIMURA, K.; EVANS, A. F.; BENNETT, M. A. A system for automated seed vigor assessment. Seed Science and Technology, v. 29, p. 625-636, 2001.

SILVA, C. B., LOPES, M. M.; MARCOS-FILHO, J.; VIEIRA, R. D Sistema automatizado de análise de imagens SVIS e condutividade elétrica para avaliação do vigor de sementes de crotalária. Revista Brasileira de Sementes, v. 34, n. 1, p. 55-60, 2012. http://dx.doi.org/10.1590/S010131222012000100007

TOHIDLOO, G.; KRUSE, M. Development of an image analysis aided seedling growth test for winter oilseed rape and verification as a vigor test. Seed Science and Technology, v. 37, p. 98-109, 2009.

TORRES, S. B.; CARVALHO, I. M. S. Teste de envelhecimento acelerado em sementes de quiabo. Revista Brasileira de Sementes, v. 20, n. 1, p. 209$211,1998$. 